\title{
THE ENGINEER'S DESTINY
}

\author{
President's Address
}

BY H. W. BUCK

\section{$\mathrm{T}^{\mathrm{H}}$} HERE has been much discussion concerning the position of the engineer in modern times, but conditions are changing so rapidly and points of view are undergoing such a fundamental evolution that it is well from time to time to review the relations of the engineer to his surroundings and to secure if possible the proper orientation.

The change and improvement in the engineer's position in the world in recent years has been so rapid as to surprise even those who were the optimists in the under-dog days of the engineering profession. In the middle of the last century, when the engineering and technical schools began to be formed in this country by men of far-seeing vision, the classical scholars looked on askance and took pains to differentiate these upstart institutions from their own traditional schools of learning and to ostracize those who pursued the new courses by classifying the professions as "learned" and technical.

Times fortunately have changed. The engineering profession is coming into its own. To-day the engineer is being swept along with an irresistible force, by a tide which he himself has created, and it is well therefore for the engineer to take his eyes off his work occasionally and to observe his constantly changing surroundings. A flood of scientific and technical accomplishment has swept over the face of the earth, revolutionizing life, commerce and international destinies. Even the turmoil in which the world now finds itself can probably in the last analysis be traced to the over acceleration of world affairs resulting from the work of the scientist and engineer.

During all this development period of the engineering profession during the past century the engineer has worked his way along alone and in silence, so to speak, seeking his reward rather in the joy of accomplishment and in the realization of his dreams 
than in worldly recognition and accumulation. The very inherent greatness of the pioneers who have laid the foundations upon which we now build prevented them in a way from acquiring a more worldly position in affairs. This tradition, however, is not a virtue beyond a certain point, and the engineer by nature is too willing to give way to others. The time has come when he should take a more worldly position in the world which he himself has created.

In our general relations to intellectual development we may consider that we are just emerging from a classical period where tradition, custom, prejudice, ignorance and dogmatic religion were the controlling forces. Movements which took place in world affairs were largely political, following the paths best suited to the advantage of the ruling classes. There was little real progress, because there was no development of scientific knowledge and its application in engineering. Scientific truth held no standing. The worship of tradition caused a powerful reaction against any scientific discovery which might necessitate a readjustment of established habits of thought and life.

For centuries before the dawn of the scientific and engineering era great changes took place throughout the world, but little real progress occurred. Races rose and fell, always falling back to the starting point, for there can be no upward trend in racial development without the solid basis of scientific knowledge to grow upon. China made great progress and developed its early civilization under scientific activity but during recent centuries it has lived under the worship of classical tradition and has become inert.

A constant change in point of view, which is so largely brought about through developments in scientific knowledge, seems to be necessary for progress in civilization. Our civilization to-day differs from that of a century ago in proportion to the scientific and engineering evolution which has taken place during the period through its reactions on life in all of its phases. Such discoveries in science as the law of gravitation, the evolution in species, the laws of electro-magnetic induction, etc., have probably had a more profound effect upon the development of the human race than any other acts in history.

The engineering profession has passed through the preliminary stages of its growth and has reached a position where the engineer should work and act not only with proper attention to his work itself but with full consciousness of the important relation of his 
work to human affairs in general. Among the early pioneers in engineering were many notable instances of men of great breadth of view. Men like Watt, Fulton, Whitney, McCormick, Erickson and others. Specialization had not at that time begun to work its narrowing influences. Of recent years, however, under the stress of commercial development and economic conditions, increasing specialization has taken place and the engineer has become obliged to compass his mind with an ever narrowing horizon. This specialization produces extraordinary proficiency in particular fields, but has the objectionable effect of narrowing the character and outlook of the man and of reducing his value as a citizen. We must take care lest commercial considerations and the modern mania for efficiency in the narrow sense does not force our engineers to lose sight of the world around them in their concentrated attention to the part rather than to the whole. This excessive specialization is a danger which threatens the future standing of the engineer.

It is interesting to recall in this connection the results of a recent canvass made by a joint Committee on Education on the qualities which, in the opinion of some five thousand leading men, engineers and others, best fitted a man for a successful career as an engineer. As a result of this vote only 13 points out of 100 were assigned to purely technical knowledge as an essential, the other 87 points being allotted to broader qualifications such as judgment, character, human understanding, etc. This is merely a quantitative statement of the many general demands now being made of the engineer and it illustrates how the work of the engineer can be broadened out. It is an encouraging symptom.

A most significant movement of recent times in the engineering world has been the development of cooperative action among engineers of all classes, and this tendency will, I believe, serve to offset the evils of specialization. It is the growing recognition of the fact that all branches of engineering are interdependent. We electrical engineers, I believe, are well aware how much we need the assistance of other branches of engineering for the successful fulfillment of our purpose.

This cooperative movement has quite recently been given tangible expression in the formation of the Engineering Council, an act, I believe, of far-reaching consequence. Under this organization as a beginning the Civil, Mechanical, Mining and Electrical Societies together with the United Engineering Society are 
tied together for cooperative action through a joint body of twenty-four representatives. This body will meet at frequent intervals and will deliberate on matters of general interest to engineers. It is an encouraging beginning toward universal cooperation among engineers in all branches of work.

In this Engineering Council we have for the first time an engineering body representing some thirty thousand engineers of sufficient scope and standing to create an engineering public opinion. Its influence is likely to be far-reaching in building up the prestige of engineers in both technical and civic affairs.

A further development which has reached full recognition only in recent times is the mutual appreciation which has grown up between the engineer and the worker in pure science. The engineer looks to the scientist to provide him with raw materials of knowledge with which to work out his applications, and the scientist must look to the engineer to make his discoveries so fruitful that the full effectiveness of his work on the frontier of research can be sustained. Both are working together in order to unfold nature in the most effective way for the benefit of man.

We electrical engineers, I think, feel a particularly close bond with the pure scientist in that recent developments in physical science have disclosed an intimate relationship between electrical phenomena and the nature of energy and matter.

All of the important movements which are taking place at the present time, which center around the engineer and his work mean, I believe, that the engineer is soon going to leave his position of isolation in independent fields of work and realize that he owes an obligation to the community broader than his daily engineering work, and will contribute to the general welfare his talents and experience. It matters not whether the problems before him are political, sociological, industrial or technical, I believe that the engineering type of mind, if the proper breadth of view has been acquired, is best fitted to undertake them.

It is not necessary, perhaps, in important administrative positions to have civil, electrical or mechanical engineers as such, but we do need men in those positions who have had training of the type which engineering gives, with the mental balance, the power of analysis which such a training develops, the resourcefulness and the faculty of recognizing and properly apportioning the various elements in a problem. There is a quality of mental honesty which engineering experience highly develops which is 
sorely needed in public life. The scientific and engineering professions should rise up and furnish such men from their ranks for the best welfare of the country.

The classicist contends that a world dominated by scientists and engineers would be cold, materialistic and atheistic and lacking in those qualities of art and sentiment and the imaginative outlook which every civilization so highly prizes. To this doctrine and its injustice to the engineer I want to take emphatic exception. The world today may be inclined toward materialism but it is not dominated by the engineer, far from it, but by other classes. The engineering mind on the other hand is characterized by a highly developed creative imagination and possesses to a high degree exactly those qualities of mind and temperament best suited to combat materialism. There have been many instances in history of great artists who have been great engineers and vice versa, and I believe that the two temperaments lie in close relationship. Furthermore, scientists and engineers as a class, have a strongly developed spirit of international understanding and sympathy which may serve as an important safeguard against excessive nationalism and aggression.

And so, gentlemen, I believe that we can confidently look forward to a new era for the proper fulfillment of the destinies of the engineer. Out of this world chaos we now see men of engineering and scientific training rising to positions of commanding prominence on all sides. It is simply the working of the inevitable law of the survival of the fittest.

In this great movement not only must the individual engineer play his part, but the great engineering societies must realize the power of influence which they are developing in an ever increasing degree in the community and the obligations which devolve upon them.

And so I hope that the American Institute of Electrical Engineers as it passes along from one administration to another will acquire an increasing realization of its duty, not only in furthering the growth of science and engineering, but in furthering the influence of the engineer in the affairs of the country and of the world. 